\title{
Family functioning and environmental resources offered by families of children with mental disorders
}

\author{
Eduarda Souza Dilleggi, ${ }^{\prime}$ Ana Paula Rosa, ${ }^{\prime}$ Patricia Leila dos Santos ${ }^{2}$
}

1 Escola de Enfermagem de Ribeirão Preto, Universidade de São Paulo, Ribeirão Preto, Brazil.

2 Departamento de Neurociências e Ciências do Comportamento Faculdade de Medicina de Ribeirão Preto, Universidade de São Paulo, Ribeirão Preto, Brazil.

\section{Correspondence:}

Eduarda Souza Dilleggi

Escola de Enfermagem de Ribeirão

Preto, Universidade de São Paulo.

Ten. Catão Roxo Street, 2650, Room

32. Ribeirão Preto, SP, Brazil. Postal

14051-140.

Phone: 55 (16) 3315 - 4608

Email: eduardadilleggi@gmail.com

Received: 7 January 2019

Accepted: 25 September 2019

\section{Citation:}

Dilleggi, E. S., Rosa A. P., \& Santos, P. L. (2019). Family functioning and environmental resources offered by families of children with mental disorders. Salud Mental, 42(5), 235 242

DOI: $10.17711 /$ SM.0185-3325.2019.030

\begin{abstract}
Introduction. The presence of mental disorders in a family may cause various losses in its functioning and characteristics. Objective. To determine which environmental resources are offered to children with mental disorders by their families and how they correlated with the family functioning. Method. The study included a total of 33 persons responsible for children with mental disorders. The subjects responded to two questionnaires to characterize family functioning (FACES IV) and the availability of resources in the family environment (RAF). Data were analyzed in a descriptively and the Spearman correlation test was used to identify associations between variables. Results. Most of the children were male and attended school, and the most frequent psychiatric diagnoses were attention deficit and hyperactivity disorder and autism spectrum disorder. Most families were considered to have good family functioning $(87.9 \%)$, with only $12.1 \%$ being considered dysfunctional. Regarding environmental resources, the highest mean values were assigned to the presence of toys $(6.9 \pm 2.0)$ and to family gatherings for routine activities $(6.6 \pm 2.3)$. Family cohesion, flexibility, communication, and satisfaction (functional) were positively correlated with the offer of activities and resources and negatively correlated with unbalanced (dysfunctional) subscales. Discussion and conclusion. Children's mental disorders do not appear to affect family dynamics in a significant manner. However, family functioning interferes with the types of activities and resources it offers to the child and that may have an impact on his/ her development.
\end{abstract}

Keywords: Family functioning, family environment, mental disorders, child, protective factors.

\section{RESUMEN}

Introducción. La presencia de un trastorno mental en una familia puede causar varias pérdidas en su funcionamiento y sus características. Objetivo. Determinar qué recursos ambientales reciben de sus familias los niños con trastornos mentales y cómo se correlacionan con el funcionamiento familiar. Método. El estudio contó con la participación de un total de 33 personas responsables de niños con trastornos mentales. Los sujetos respondieron a dos cuestionarios para caracterizar el funcionamiento familiar (FACES IV) y la disponibilidad de recursos en el entorno familiar (RAF). Los datos se analizaron de manera descriptiva y la prueba de correlación de Spearman se utilizó para identificar asociaciones entre variables. Resultados. La mayoría de los niños eran del sexo masculino y asistían a la escuela, y los diagnósticos psiquiátricos más frecuentes fueron el trastorno por déficit de atención e hiperactividad y el trastorno del espectro autista. Se consideró que la mayoría de las familias tenían un buen funcionamiento familiar ( $87.9 \%$ ), y sólo el $12.1 \%$ se consideró disfuncional. Con respecto a los recursos ambientales, los valores medios más altos se asignaron a la presencia de juguetes $(6.9 \pm 2.0)$ y a las reuniones familiares para actividades de rutina $(6.6 \pm 2.3)$. La cohesión familiar, la flexibilidad, la comunicación y la satisfacción (funcional) se correlacionaron positivamente con la oferta de actividades y recursos y se correlacionaron negativamente con subescalas desequilibradas (disfuncionales). Discusión y conclusión. Los trastornos mentales de los niños no parecen afectar la dinámica familiar de manera significativa. Sin embargo, el funcionamiento familiar interfiere con los tipos de actividades y recursos que ofrece al niño o niña, lo que puede tener un impacto en su desarrollo.

Palabras clave: Funcionamiento familiar, entorno familiar, trastornos mentales, infantil, factores protectors. 


\section{INTRODUCTION}

Children with mental disorders generally depend on family attention and support since they require more intensive care and need help, time, and supervision in daily activities (administration of medication, treatment routine, coping with problematic behaviors, school activities, and support in stigmatizing situations, among others) (Campelo, Costa, \& Colvero, 2014; Buriola, Vicente, Zurita, \& Marcon, 2016; Farias, Lima, Ferreira, Cruzeiro, \& Quevedo, 2014).

Mental disorders can result in losses in various areas of development including interpersonal relations and social insertion, which may generate problems of family functioning and dynamics (de Souza Nunes, \& Werlang, 2008). Another important grievance concerns academic performance and learning difficulties, which will also have an impact on all areas of development (de Magalhães Monteiro \& Santos, 2013; Pereira, et al., 2015; Petrucci, Borsa \& Koller, 2016).

The family is the first environment that helps the child in the process of socialization by teaching, counseling, and providing affection, values, and physical and emotional care; it is also the major source of social support of an individual (Minuchin, 1990). It is within this context that daily activities take place and can promote independence, autonomy, the use of resources, and the development of interpersonal relations (Short, Eadie, Descallar, Comino, \& Kemp, 2017; Cid, 2015; Flores, Salum, \& Manfro, 2014). Despite the importance of the family, there is a scarcity of studies focusing on the family environment of these children and on analyzing its different, positive or negative, conditions that may interfere with child development and family functioning.

The daily routine of the family of a child with a mental disorder is altered, with a frequent reduction of the participation in events and changes in social habits and in the relationship among family members. Consequently, there may be a social isolation of the child and commonly an overprotective attitude on the part of the parents, which limit their participation in a series of activities (Vicente et al., 2013; Hock \& Ahmedani, 2012; Gomes, Martins \& Amendoeira, 2011). This is also due to the behavioral problems of the children, the difficulty in dealing with them, and the feeling of shame experienced by the family (Day et al., 2018; Green et al., 2016).

Thus, the family environment may represent a protective factor (by offering support and opportunities) or a higher risk (by limiting social participation and activities) for child development. Within this context, an interaction between parents and children plays a fundamental role because, within the bioecological model, this context is interconnected with all other contexts in which the child participates (Wright, Masten, \& Narayan, 2013; Bronfenbrenner, 2011).

Children with mental disorders have behavioral and/ or emotional problems, with difficulty in social relations and in following norms and rules, with functional losses re- garding autonomy and daily life (Dumas, 2011). Boys are more affected, with hyperactivity symptoms predominating among them. Several studies have reported that about 3\% to $7 \%$ of these children are of school age and one of their more significant types of impairment involves the activities related to learning, which are interlinked with all areas of development (Belli, Muszkat, \& Cracasso, 2015; Polanczyk, Salum, Sugaya, Caye, \& Rohde, 2015; Ercan, Bilaç, Özaslan, \& Ardic, 2016; Hillen \& Gafson, 2015; Kato, Yanagawa, Fujiwara, \& Morawska, 2015).

Depending on the attitude of the parents or other relatives living in the same environment, the presence of a person with a mental disorder may increase or reduce the family interactions (Green et al., 2016). Thus, the approach can be seen as a form of coping with adversity, becoming established as a protective factor (Rolland, 2016; Wang, \& Zhao, 2012). It is known that a family with healthy functioning has a positive influence on child development by promoting prosocial behaviors (Renzaho, Mellor, Mccabe, \& Powell, 2013).

On the other hand, the family's approach to the child may be seen as a condition of risk for development. The child with mental disorders requires greater attention and care with constant supervision and at times is not stimulated in terms of the process of autonomy, becoming a source of care overload, as well as a target of overprotection by the parents or caregivers (Buriola et al., 2016; Flores et al., 2014). The mental disorders of children cause significant changes for the family either because of their particular characteristics or because of the need to reorganize the environment in order to meet the child's requirements.

The objective of the present study was to determine which environmental resources are offered to children with mental disorders by their family and how they correlated with the family functioning.

\section{METHOD}

\section{Participants}

This is a cross-sectional study which conducted between August 2016 to April 2017, with 33 caregivers (parents or grandparents) of children, who attended at the ambulatory service of psychiatry of a general hospital in Ribeirão Preto, São Paulo, Brazil. Sample size was calculated based on the total sampling, made up by 51 patients in total.

Inclusion criteria were self-report of being the child's primary caregiver and 18 years or older. The child should be between 6 and 12 years old and diagnosed with a mental disorder by psychiatrist. Exclusion criteria were caregivers with mental disorders and children with other health conditions that could interfere with family functioning and offer 
of resources, as reported in the literature (Ribeiro, Vandenberghe, Prudente, Vila \& Porto, 2016; Macedo, Silva, Paiva, \& Ramos, 2015).

The majority of participants/caregivers were mothers (78.8\%), followed by parents (15.2\%) and grandparents $(6.1 \%)$. The mean age was 37.6 years $(S D=8.6)$, and $87.9 \%$ of respondents identified themselves as the primary caregiver of the child.

\section{Instruments}

\section{Sociodemographic questionnaire}

This questionnaire was constructed by the researchers with the purpose of characterizing families; it contains 25 questions about personal data and socioeconomic conditions (Associação Brasileira de Empresas de Pesquisa-ABEP, 2014).

Family Adaptability and Cohesion Evaluation Scale, version IV (FACES IV)

This scale, which is used to measure family cohesion and flexibility, was elaborated by Olson (2008) and adapted to Brazil (Santos, Bazon, \& Carvalho, 2017; Santos, Bazon, Carvalho, Minetto, Crepaldi, \& Boing, 2013). The scale contains 42 items divided into six main subscales: two of them balanced (cohesion and flexibility) and four unbalanced (disengaged, enmeshed, rigid and chaotic - extreme conditions of cohesion and flexibility), and includes 20 additional items divided into two complementary subscales - communication and family satisfaction (10 items each). In the construct of the instrument, cohesion refers to emotional/affective bonds, independence among family members, limits and decision making, and flexibility refers to the ability of family members to change the family structure, roles, and rules in the presence of adversities. The instrument consists of a series of statements to be answered according to a Likert-type 5-point scale. The results can be calculated based on the combination of scores and percentiles of the balanced and unbalanced scales (ratio), allowing to differentiate between healthy families (functional, ratio $\geq 1$ ) and unhealthy families (dysfunctional, ratio $<1$ ). For the balanced and complementary subscales, the higher the score, the healthier the family. For the unbalanced subscales, the higher the score, the greater the family dysfunction. Reliability studies according to Olson (2011) and in the present study with Cronbach's Alpha of .83 .

\section{Family Environment Resources Inventory (RAF)}

This is an instrument based on the bioecological concept of development that assesses the resources of the family environment considering three domains: resources that promote proximal processes, activities that stabilize family life, and parental practices that promote the family-school relation- ship (Marturano, 2006). The inventory is applied in the form of an interview organized into ten topics: recreational activities in the home/neighborhood, family outings, programmed and regular activities, joint home activities with parents/persons responsible, availability of toys, newspapers, magazines and books, school support and supervision, organization of schedules, and family gatherings for routine activities. The result is given by the score for each topic. The study of the instrument presented satisfactory reliability index between .70 to .84 of Cronbach's alpha (Marturano, 2006), which was confirmed in the present study $(\alpha=.84)$.

\section{Procedure}

Participants were approached in the waiting room of the psychiatry service and referred to the doctor's office to be informed about the details of the investigation, to give written informed consent, and to answer the questionnaires individually.

The study protocol was approved by the Ethics Committees for Research on Human Beings of the Nursing School of Ribeirão Preto and of the University Hospital of the Faculty of Medicine of Ribeirão Preto, University of São Paulo (CAAE: 56525416.2.0000.5393). All participants gave written informed consent to participate in the study.

\section{Statistical analysis}

The data were organized and the analyses were performed using the SPSS software, version 24.0. The frequency and percentage of the categorical variables were then calculated, together with the central tendency measures for the numerical variables. The Spearman correlation test was applied to determine the associations between family functioning (FACES IV) and the availability of resources in the family environment (RAF).

\section{RESULTS}

A total of 33 caregivers (parents or grandparents) of children, aged between 6 to 12 years old $(\mathrm{M}=8.3, S D=1.86)$; $69.7 \%$ were boys and $30.3 \%$ were girls; $78.8 \%$ frequented school. The most frequent diagnoses were: attention deficit hyperactivity disorder (39.4\%), and autism spectrum disorder $(39.4 \%)$, followed by oppositional defiant disorder (12.1\%), and schizophrenia (12.1\%). Psychiatric comorbidities were present in $24.2 \%$ of the patients. In relation to other caregiver information, Table 1 presents such results.

The results of family functioning (FACES IV) indicated that $12.1 \%$ (4) of the families were dysfunctional. The mean balanced cohesion score was higher than the flexibility score, and in the unbalanced subscales the highest means 
Table 1

\begin{tabular}{lrr} 
Characterization of the responsible and family & & \\
\hline Variable & $n$ & $\%$ \\
\hline Education & 2 & 6.1 \\
$\quad$ Illiterate / Elementary incomplete (up to 3rd) & 3 & 9.1 \\
Up to 4th grade complete & 15 & 45.5 \\
$\quad$ Complete fundamental & 9 & 27.3 \\
$\quad$ Complete middle & 4 & 12.1 \\
$\quad$ Graduated & 19 & 57.6 \\
Occupational situation & 11 & 33.3 \\
$\quad$ Working / conducting occupational activity & 3 & 9.1 \\
$\quad$ Does not work, but receives some remuneration, \\
$\quad$ pension, retirement & & \\
$\quad$ Does not work & 8 & 24.2 \\
Marital status & \\
$\quad$ Without partner / resident in the same household & & \\
$\quad$ With partner / resident in the same household & 25 & 75.8 \\
\hline
\end{tabular}

were observed for the enmeshed (excessive approximation between members with little opportunity for privacy) and the rigid (strict adherence to norms and rigidly defined functions) features (Table 2).

The offer of toys, family gatherings for routine activities, and joint home activities with the parents were the resources most frequently offered by the families, whereas there was little offer of programmed and regular activities (extracurricular activities) (Table 3).

The correlation results are presented in Table 4. The subscales of recreational activities at home/neighborhood, programmed and regular activities, school support, and supervision did not correlate with family functioning. The strongest correlation detected was family cohesion and family gathered for routine activities $(r=.515)$. The scales associated with family dysfunction (disengaged, enmeshed, and chaotic) always showed negative correlations with the availability of resources in the environment. Rigidity of family norms and rules was not correlated with the topics investigated by the RAF (Table 4).

Table 2

Mean and standard deviation (SD) values for the subscales that assess family functioning

\begin{tabular}{lcc}
\hline Subscales & Minimum - Maximum & Mean $( \pm S D)$ \\
\hline Cohesion & $16-35$ & $29.0( \pm 4.69)$ \\
Flexibility & $13-35$ & $26.3( \pm 4.64)$ \\
Disengaged & $9-24$ & $16.7( \pm 4.45)$ \\
Enmeshed & $16-33$ & $22.5( \pm 3.72)$ \\
Rigid & $8-32$ & $23.2( \pm 4.52)$ \\
Chaotic & $7-25$ & $17.1( \pm 4.30)$ \\
Communication & $16-50$ & $38.7( \pm 7.14)$ \\
Satisfaction & $12-47$ & $31.4( \pm 7.49)$ \\
\hline
\end{tabular}

Table 3

Mean and standard deviation (SD) values for the topics referring to the resources of the family environment

\begin{tabular}{lcr}
\hline Subscales & Minimum - Maximum & Mean $( \pm S D)$ \\
\hline $\begin{array}{l}\text { Recreational activities at } \\
\text { home/neighborhood }\end{array}$ & $1.4-10$ & $5.1( \pm 2.13)$ \\
$\begin{array}{l}\text { Family outings } \\
\text { Programmed and regular }\end{array}$ & $.5-6.8$ & $3.5( \pm 1.82)$ \\
$\begin{array}{l}\text { activities } \\
\text { Joint activities with the parents }\end{array}$ & $.9-4.4$ & $.8( \pm 1.11)$ \\
at home & $2.6-10$ & $6.0( \pm 2.15)$ \\
Toys & $.9-8.1$ & $6.9( \pm 2.00)$ \\
Newspapers and magazines & $1-8$ & $4.2( \pm 1.68)$ \\
Books & $0-8.8$ & $5.6( \pm 1.64)$ \\
School support and supervision & $0-10$ & $5.9( \pm 2.52)$ \\
Organization of schedules & $0-10$ & $6.6( \pm 2.29)$ \\
Family gathered for routine & $16.9-72.3$ & $47.6( \pm 12.55)$ \\
activities & & \\
Total RAF &
\end{tabular}

\section{DISCUSSION AND CONCLUSION}

The main objective of the present study was to evaluate the functioning of families who have a child with a mental disorder and to determine whether they offer resources to their children within the family environment. Our attempt was thus to determine an association between these variables.

Regarding family functioning, analysis of the results obtained revealed that most families $(87.9 \%)$ showed good functioning despite the presence of a mental disorder of a child.

On the basis of these results and of the analysis of the mean scores for the FACES IV subscales, we may infer that a possible strategy found by the family in order to cope with the disease and the treatment of the child is related to the strengthening of ties among the family members (cohesion), at times with some enmeshed relationships. Adherence to family rules and a strict definition of the roles of the family members (Rigid subscale) may also be used as a strategy for the maintenance of the health of the family group.

Similar results were obtained in a previous study that observed that the families of children with mental disorders showed higher cohesion scores and exhibited more frequently a functioning of the enmeshed type when compared to the families of children with no diagnosis of psychopathologies (Pepe, Tortolani, Gentile, \& Di Ciommo, 2015). This study reported that families with the presence of a psychopathology showed more chaotic-enmeshed and flexible-enmeshed family typologies, indicating a tendency of these families to enmeshment of the relationships.

Conversely, another study detected that the presence of children with behavioral problems is associated with less effective family functioning (Jellett, Wood, Giallo, \& Seymour, 2015; Sikora et al., 2013). 
Table 4

Significant correlations between the subscales of family functioning and the resources of the family environment (Spearman Correlation)

\begin{tabular}{lccccccc}
\hline & \multicolumn{6}{c}{ Subscales referring to family functioning Correlation coefficient $(r)$} \\
\cline { 2 - 7 } Resources & CO & $F L$ & $D E$ & $E N$ & $C H$ & $C M$ & $S$ \\
\hline Family outings & $.470^{* *}$ & - & $-.400^{*}$ & $-.368^{*}$ & - & - & $.416^{*}$ \\
Joint home activities with the parents & - & - & $-.371^{*}$ & - & - & - & - \\
Toys & $.348^{*}$ & - & $-.348^{*}$ & - & $-.389^{*}$ & $.452^{* *}$ & - \\
Newspapers and magazines & - & - & - & $-.484^{* *}$ & - & - & $.361^{*}$ \\
Books & - & - & $-.421^{*}$ & $-.445^{* *}$ & $-.394^{*}$ & $.476^{* *}$ & - \\
Organization of schedules & $.409^{*}$ & $.350^{*}$ & - & - & - & $.500^{* *}$ & - \\
Family gathered for routine activities & $.515^{* *}$ & $.470^{* *}$ & $-.363^{*}$ & $-.364^{*}$ & $-.386^{*}$ & $.395^{*}$ & $.465^{* *}$ \\
Total RAF & $.453^{* *}$ & - & $-.449^{* *}$ & $-.385^{*}$ & $-.363^{*}$ & $.417^{*}$ & - \\
\hline
\end{tabular}

Notes: $\mathrm{CO}=$ cohesion; $\mathrm{FL}=$ flexibility; $\mathrm{DE}=$ disengaged; $\mathrm{EN}=$ enmeshed $\mathrm{CH}=$ chaotic $\mathrm{CM}=$ communication; $\mathrm{S}=\mathrm{Satisfaction}$. ${ }^{*} p<.05,{ }^{* *} p<.01$

The present results are also similar to those obtained in a study of adolescents with schizophrenia, which reported that most of the families showed healthy functioning (Wiguna et al., 2015). The present authors, however, detected a higher percentage of families defined as dysfunctional ( $24.4 \%$ compared to $12.1 \%$ in the cited study). This discrepancy may be due to a variation of age (adolescents vs. children) and to the difference associated with the mental disorder (schizophrenia vs. various mental disorders), or also due to the cultural diversity of the contexts within which the studies were conducted.

Demographic variables may explain variations of cohesion in the families of children with different mental disorders. The educational level of the parents and the family income have been previously pointed out as predictors of cohesion in the presence of this condition (Rieger \& Mcgrail, 2013).

When compared to other Brazilian studies conducted on clinical samples, the present results concerning the resources of the family environment were in general slightly better than those observed among children with learning problems, except for data regarding the organization of schedules for routine activities (D'Avila-Bacarji, Marturano, \& Elias, 2005). In addition when compared to data obtained for a sample with behavioral problems the present results were similar or better, except for programmed and regular activities (Ferreira \& Marturano, 2002).

A study conducted on children with cerebral palsy detected higher values for different resources, except for three topics for which it detected similar or higher values than the present ones: organization of schedules (5.9 in both studies), school support and supervisions (5.6 in this study and 4.5 in the cited study) and family gathered for routine activities (with values of 6.6 in the present study and of 6.5 for children with cerebral palsy) (Morilla, Caldas, Scarpellini, $\&$ Santos, 2017). These divergences in samples from the same sociocultural context may indicate that mental health problems place the children in a more vulnerable condition regarding development than physical health problems or impaired physical/motor development, as is the case for cerebral palsy.

We should consider differences not only between sample profiles, but also in the form of conducting the interview in order to respond to the inventory. Also, it is important to remember that the studies were conducted at different times (10 years of difference), with increased discrepancy between samples. The profile of the children and of the mental disorders changed a long time, with the advancement of society and with new discoveries in the area of mental health and other related sciences.

The bioecological conception of development (the approach at the basis of the construction of the RAF instrument) emphasizes the importance of the replication of investigations that might reaffirm the findings of previous studies, pointing out the stable elements of development as well as the changes that occur over various generations (Bronfenbrenner, 2011). The RAF instrument itself was constructed in order to identify risk and protective factors in the family environment, although it did not incorporate the technological changes and the new resources offered over time to children.

Although various resources may be present in the homes of the families investigated, the programmed and regular activities (extracurricular experiences) are those least cited. In general, these activities are considered to be important contexts for development in view of the diversity of experiences that they provide, such as interaction with peers and with non-family adults, and the contact with rules and routines differing from those experienced at home and in school. The benefits have been pointed out, especially regarding academic engagement and performance and the development of prosocial behavior (Hughes, Cao, \& Kwok, 2016; Pereira et al., 2015). 
The literature indicates that practicing sports, having responsibilities in the home routine, and having at least one parent involved in leisure activities (community activities, sport or a hobby) are conditions more present among adolescents considered to be healthy or free of psychiatric disorders, possibly representing protective factors against mental disorders (Borkum et al., 2017).

At this point, we should consider the fact that the present study showed that most children frequented school, although a good part of them were outside the educational system, excluded from one more context in which the social interactions represent a key element for the development of different skills.

In addition, several investigations have indicated that social environments, such as the family, peer groups, school, and neighbors, are associated with better results in development. In particular, the family context and the groups of friends have been shown to be protective factors for child development (Wlodarczyk et al., 2017; Pereira et al., 2015).

In this respect, the present findings indicate a predominance of home activities with lower scores (which implies a lower occurrence) for activities in the neighborhood and outside the home (extracurricular activities and outings), with a consequent increase in the amount of time the relatives devote to these children (Sikora et al., 2013). It is possible that, due to the behavioral characteristics of the children (a predominance of ADHD and ASD), the parents do not feel encouraged to expose their child to environments outside the home. We should also consider the stigma created by the mental disorder, which inhibits the family regarding the search for spaces where social interaction with peers and adults might occur (Wlodarczyk et al., 2017). Activities that permit interaction with other people are fundamental for child development (Bayer et al., 2011).

Regarding the associations between family functioning and the resources of the family environment, the dimensions favorable to family functioning such as cohesion and communication showed positive associations with different family resources, in agreement with the results of a study on children with cerebral palsy conducted with similar objectives (Morilla et al., 2017). Conversely, the unbalanced cohesion extremes (related to the disengaged and enmeshed subscales) showed negative correlations with family resources.

The associations between environmental resources and unbalanced dimensions (including the chaotic subscale) clearly show that a problematic family dynamics reduces the possibility that the child will have materials and activities that could be of benefit for his development, strengthening his abilities and minimizing the effect of the risks due to the presence of a mental disorder.

Several studies have indicated that adversities during childhood have proved to be associated in a negative man- ner with family cohesion and flexibility. However, when family functioning is well adapted its members can develop in a satisfactory manner (Oshri et al., 2015; Muniz, Silver, \& Stein, 2014). We may infer that, despite the presence of a mental disorder that may trigger a series of difficulties for both the child and the family, the families that establish affective closeness among its members with good cohesion and that have good communicative skills are able to offer more stimuli to the child, thus becoming promoters of development.

In general, belonging to a family with problematic functioning seems to increase the risk of maladapted development since these families are unable to provide resources or opportunities that may stimulate the development of its members. Growing up within adverse family contexts may impair psychosocial and emotional development and may frequently have an impact on future mental health (Luecken, Roubinov, \& Tanaka, 2013).

On the other hand, the study contributes by indicating that aspects such as family cohesion and communication are favorable to development when they are strengthened. Future research directions should investigate how the type of mental disorder of the child interferes with the offer of resources by the family and focus on the variability of the functioning profile according to the type of psychopathology.

It is also important to understand the perception of the family about the activities and materials that may help children with mental disorders to develop different types of competence. In addition, investigations are needed in order to understand the processes by which the offer of resources and a healthy family dynamic may act as promoters of the development of the child.

The presence of mental disorders is not always associated with family dysfunction, although it seems to have some impact on the type of resources and activities the family offers to the child, especially giving the child the opportunity to participate in diverse social contexts. Affective closeness between family members and communicative skills seem to favor the greater variety of resources and activities to which the family exposes the child. The types of activities and the materials offered by the family may possibly vary according to the characteristics of the psychopathology.

\section{Limitations}

The present study has some limitations both regarding the possibility of generalization of its results by including a restricted group of participants and regarding the strategy used to investigate the resources of the family environment, since the instrument was developed for the Brazilian context and was not updated to incorporate new resources that may be available (electronic equipment and the internet). 


\section{Funding}

This study was partially funded by CAPES - Comissão de Aperfeiçoamento de Pessoal do Nível Superior (N 33002029016P9).

\section{Conflict of interests}

The authors declare they have no conflicts of interest.

\section{Acknowledgements}

We are grateful to all families and to the team of the Service of Child and Adolescent Psychiatry that contributed to the study. We also wish to thank the research collaborators who helped with data collection. We thank CAPES (Comissão de Aperfeiçoamento de Pessoal do Nível Superior) for a Postgraduate fellowship granted to the senior author.

\section{REFERENCES}

Associação brasileira de empresas de pesquisa. (2014). Retrieved from http://www. abep.org/criterio-brasil

Bayer, J. K., Ukoumunne, O. C., Lucas, N., Wake, M., Scalzo, K., \& Nicholson, J. M. (2011). Risk factors for childhood mental health symptoms: National longitudinal study of Australian children. Pediatrics, 128(4), e865-e879. doi: 10.1542/peds.2011-0491

Belli, A. A., Muszkat, M., \& Cracasso, S. P. (2015). Rede de apoio social na vida do indivíduo com transtorno de déficit de atenção e hiperatividade e seus cuidadores. Revista Psicopedagogia, 32(98), 200-204. ISSN 0103-8486

Borkum, D. B., Temes, C. M., Magni, L. R., Fitzmaurice, G. M., Aguirre, B. A., Goodman, M, \& Zanarini, M. C. (2017). Prevalence rates of childhood protective factors in adolescents with BPD, psychiatrically healthy adolescents and adults with BPD. Personality and Mental Health, 11(3), 189-194. doi: $10.1002 / \mathrm{pmh} .1380$

Bronfenbrenner, U. (2011). Bioecologia do desenvolvimento humano: Tornando os seres humanos mais humanos. Porto Alegre: Artmed. ISBN 978-8536326153

Buriola, A. A., Vicente, J. B., Zurita, R. C. M., \& Marcon, S. S. (2016). Overload of caregivers of children or adolescents suffering from mental disorder in the city of Maringá, Paraná. Escola Anna Nery, 20(2), 344-351. doi: 10.5935/14148145.20160047

Campelo, L. L. D. C. R., Costa, S. M. E., \& Colvero, L. D. A. (2014). Difficulties of familes in caring for children and adolescents with mental disorders: an integrative review. Revista Da Escola de Enfermagem da USP, 48(SPE), 192198. doi: 10.1590/S0080-623420140000600027

Cid, M. F. B. (2015). Cotidiano familiar: refletindo sobre a saúde mental infantil e a prática de atividades familiares. Revista de Terapia Ocupacional da Universidade de São Paulo, 26(3), 428-438. doi: 10.11606/issn.2238-6149. v26i3p428-438

D'Avila-Bacarji, K. M. G., Marturano, E. M., \& Elias, L. C. D. S. (2005). Resources and adversities in the home environment of children with poor school achievement. Paidéia (Ribeirão Preto), 15(30), 43-55. doi: 10.1590/S0103863X2005000100007

Day, K. L., Dobson, K. G., Schmidt, L. A., Ferro, M. A., Saigal, S., Boyle, M. H., \& Van Lieshout, R. J. (2018). Exposure to overprotective parenting and psychopathology in extremely low birth weight survivors. Child: Care, Health and Development, 44(2), 234-239. doi: 10.1111/cch.12498

Dumas, J. E. (2011). Uma abordagem descritiva, desenvolvimental e relacional. In Dumas, J. E. (3 eds.), Psicopatologia da infância e da adolescência (pp. 13-53). Porto Alegre: Artmed. ISBN 9782804155384

Ercan, E. S., Bilaç, Ö., Özaslan, T. U, \& Ardic, U. A. (2016). Prevalence of psychiatric disorders among Turkish children: the effects of impairment and sociodemographic correlates. Child Psychiatry \& Human Development, 47(1), 35-42. doi: 10.1007/s10578-015-0541-3

Farias, C. D. A., Lima, P. O. C., Ferreira, L. A., Cruzeiro, A. L. S., \& Quevedo, L. D. A. (2014). Sobrecarga em cuidadores de usuários de um centro de atenção psicossocial infanto-juvenil no sul do Brasil. Ciência \& Saúde Coletiva, 19(12),
4819-4827. doi: 10.1590/1413-812320141912.19182013

Ferreira, M. D. C. T., \& Marturano, E. M. (2002). Home enviroment and behavior problems presented by school underachieving children. Psicologia: Relexão e Crítica, 15(1), 35-44. doi: 10.1590/S0102-79722002000100005

Flores, S. M., Salum, G. A., \& Manfro, G. G. (2014). Dysfunctional family environments and childhood psychopathology: the role of psychiatric comorbidity. Trends in Psychiatry and Psychotherapy, 36(3), 147-151. doi: 10.1590/2237-6089-2014-0003

Gomes, M. F. P., Martins, M. M., \& Amendoeira, J. (2011). As famílias com doentes mentais. Revista Portuguesa de Enfermagem de Saúde Mental, (5), 52-58. ISSN $1647-2160$

Green, J. L., Rinehart, N., Anderson, V., Efron, D., Nicholson, J. M., Jongeling, B., ... Sciberras, E. (2016). Association between autism symptoms and family functioning in children with attention-deficit/hyperactivity disorder: a community-based study. European Child \& Adolescent Psychiatry, 25(12), 1307-1318. doi: 10.1007/s00787-016-0861-2

Hillen, T., \& Gafson, L., (2015). Why good placements matter: Pre-placement and placement risk factor associated with a mental health disorders in pre-school children in foster care. Clinical Child Psychology and Psychiatry, 20(3), 486499. doi: 10.1177/1359104514530733

Hock, R., \& Ahmedani, B. K. (2012). Parent perceptions of autism severity: Exploring the social ecological context. Disability and Health Journal, 5(4), 298-304. doi: 10.1016/j.dhjo.2012.06.002

Hughes, J. N., Cao, Q., \& Kwok, O. M. (2016). Indirect effects of extracurricular participation on academic adjustment via perceived friends' prosocial norms. Journal of Youth and Adolescence, 45(11), 2260-2277. doi: 10.1007/s10964016-0508-0

Jellett, R., Wood, C. E., Giallo, R., \& Seymour, M. (2015). Family functioning and behaviour problems in children with Autism Spectrum Disorders: The mediating role of parent mental health. Clinical Psychologist, 19(1), 39-48. doi: 10.1111/cp.12047

Kato, N., Yanagawa, T., Fujiwara, T., \& Morawska, A. (2015). Prevalence of children's mental health problems and the effectiveness of population-level family interventions. Journal of Epidemiology, 25(8), 507-516. doi: 10.2188/ jea.JE20140198

Luecken, L. J., Roubinov, D. S., \& Tanaka, R. (2013). Childhood family environment, social, competence, and health across the lifespan. Journal of Social and Personal Relationships, 30(2), 171-178. doi: 10.1177/0265407512454272

Macedo, E. C., Silva, L. R. D., Paiva, M. S., \& Ramos, M. N. P. (2015). Burden and quality of life of mothers of children and adolescents with chronic illnesses: An integrative review. Revista Latino-Americana de Enfermagem. 23(4), 769-777. doi: 10.1590/0104-1169.0196.2613

de Magalhães Monteiro, R., \& Santos, A. A. A. (2013). Recursos familiares e desempenho de crianças em compreensão de leitura. Psico, 44(2), 13. ISSN 0103-5371

Marturano, E. M. (2006). The home environment resources scale. Psicologia: Reflexão e Crítica, 19(3), 498-506. doi: 10.1590/S0102-79722006000300019

Minuchin, S. (1990). Famílias: funcionamento e tratamento. Porto Alegre: Artes Médicas.

Morilla, C. M., Caldas, C. A. C. T., Scarpellini, A. C. A. V., \& Santos, P. L. (2017), Family resources and promotion of development of children with cerebral palsy. Journal of Human Growth and Development, 27(2), 166-174. doi: 10.7322/ jhgd.122707

Muniz, E. L., Silver, E. J., \& Stein, R. E. (2014). Family routines and social- emotional school readiness among preschool-age children. Journal of Developmental \& Behavioral Pediatrics, 35(2), 93-99. doi: 10.1097/DBP.0000000000000021

Olson, D. H. (2008). FACES IV Manual. Minneapolis, MN: Life Innovations.

Olson, D. H. (2011). Faces IV and the circumplex model: validation study. Journal of Marital \& Family Therapy, 37(1), 64-80. doi: 10.1111/j.17520606.2009.00175.x

Oshri, A., Lucier-Greer, M., O’Neal, C. W., Arnold, A. L., Mancini, J. A., \& Ford, J. L. (2015). Adverse childhood experiences, family functioning, and resilience in military families: A pattern-based approach. Family Relations, 64(1), 44-63. doi: $10.1111 /$ fare. 12108

Pepe, S., Tortolani, D., Gentile, S., \& Di Ciommo, V. M. (2015). Exploring the 
relationship between family functioning and psycho-pathology in a sample in the pediatric age. The Spanish Journal of Psychology, 18(12), 1-8. doi: 10.1017/ sjp. 2015.10

Pereira, S., Santos, J. N., Nunes, M. A., Oliveira, M. G., Santos, T. S., \& MartinsReis, V. D. O. (2015). Health and education: a partnership required for school success. CoDAS - Sociedade Brasileira de Fonoaudiologia, 27(1), 58-64. doi: 10.1590/2317-1782/20152014053

Petrucci, G. W., Borsa, J. C., \& Koller, S. H. (2016). Family and school in the socioemotional development in childhood. Temas Em Psicologia, 24(2), 391402. doi: 10.9788/TP2016.2-01

Polanczyk, G. V., Salum, G. A., Sugaya, L. S., Caye, A., \& Rohde, L. A. (2015). Annual research review: A meta-analysis of the worldwide prevalence of mental disorders in children and adolescents. Journal of Child Psychology and Psychiatry, 56(3), 345-365. doi: 10.1111/jcpp.12381

Renzaho, A., Mellor, D., Mccabe, M., \& Powell, M. (2013). Family functioning, parental psychological distress and child behaviours: Evidence from the Victorian child health and wellbeing study. Australian Psychologist, 48(3), 217225. doi: 10.1111/j.1742-9544.2011.00059.x

Ribeiro, M. F. M, Vandenberghe, L., Prudente, C. O. M., Vila, V. D. S. C., \& Porto, C. C. (2016) Cerebral Palsy: how the child's age and severity of impairment affect the mother's stress and coping strategies. Ciencias \& Saúde Coletiva, 21(10), 3203-3212. doi: 10.1590/1413-812320152110.17352016

Rieger, A., \& McGrail, J. P. (2013). Coping humor and family functioning in parents of children with disabilities. Rehabilitation Psychology, 58(1), 89-97. doi: 10.1037/a0031556

Rolland, J. S. (2016). Mastering family challenges in serious illness and disability. In Walsh, F. Normal Family processes: growing diversity and complexity. (4 $\left.{ }^{\mathrm{a}} \mathrm{ed}\right)$ (pp. 452-482). New York: Guilford Press.

Santos, P. L., Bazon, M. R., Carvalho, A. M. P., Minetto, M. F, Crepaldi, M. A, \& Boing, E. (2013). FACES IV: Escala de avaliação da coesão e adaptabilidade familiar-Versão $I V$. Minneapolis: Life Innovations.

Santos, P. L., Bazon, M. R., \& Carvalho, A. M. P. (2017). Family Adaptability and Cohesion Evaluation Scale IV (FACES IV): adaptação brasileira. Avaliaçao Psicologica: Interamerican Journal of Psychological Assessment, 16(2), 120-
127. doi: 10.15689/AP.2017.1602.01

Short, K., Eadie, P., Descallar, J., Comino, E., \& Kemp, L. (2017). Longitudinal vocabulary development in Australian urban Aboriginal children: Protective and risk factors. Child: Care Health and Developmet, 43(6), 906-917. doi: $10.1111 /$ cch. 12492

Sikora, D., Moran, E., Orlich, F., Hall, T. A., Kovacs, E. A., Delahaye, J., ... Kuhlthau, K. (2013). The relationship between family functioning and behavior problems in children with autism spectrum disorders. Research in Autism Spectrum Disorders, 7(2), 307-315. doi: 10.1016/j.rasd.2012.09.006

de Souza Nunes, M. M., \& Werlang, B. S. G. (2008). Transtorno de déficit de atenção/hiperatividade e transtorno de conduta: aspectos familiares e escolares. ConScientiae Saúde, 7(2), 207-216. doi: 10.5585/conssaude.v7i2.970

Vicente, J. B., Mariano, P. P., Buriola, A. A., Paiano, M., Waidman, M. A. P., \& Marcon, S. S. (2013). Acceptance of patients with mental illness: a family perspective. Revista Gaúcha de Enfermagem, 34(2), 54-61. doi: 10.1590/ S1983-14472013000200007

Wang, J., \& Zhao, X. (2012). Comparison of family functioning and social support between families with a member who has obsessive-compulsive disorder and control families in Shanghai. Shanghai Archives of Psychiatry, 24(1), 20-29. doi: 10.3969/j.issn.1002-0829.2012.01.003

Wiguna, T., Ismail, R. I., Noorhana, S. R., Kaligis, F., Aji, A. N., \& Belfer, M. L. (2015). Family responses to a child with schizophrenia: An Indonesian experience. Asian Journal of Psychiatry, 18, 66-69. doi: 10.1016/j.ajp.2015.09.009

Wlodarczyk, O., Pawils, S., Metzner, F., Kriston, L., Klasen, F., \& Ravens-Sieberer, U. (2017). Risk and protective factors for mental health problems in preschoolaged children: cross-sectional results of the BELLA preschool study. Child and Adolescent Psychiatry and Mental Health, 11(12). doi: 10.1186/s13034-0170149-4

Wright, M. O. D., Masten, A. S., \& Narayan, A. J. (2013). Resilience processes in development: four waves of research on positive adaptation in the context of adversity. In Goldstein, S., \& Brooks, R. B. Handbook of Resilience in Children. (pp. 15-37). Boston, MA: Springer US. 